\title{
A konferencia panel-összefoglalói
}

\section{Az első szakképzési törvény gazdasági- társadalmi környezete nemzetközi kitekintésben Raportöri beszámoló az 1. panelbeszélgetés munkájáról (összeállította: Králik Tibor)}

A panel vezetője: Dr. Habil Lükő István, PTE KPVK ny. egyetemi magántanár, Sopron Raportőr: Králik Tibor, főigazgató, Soproni Szakképzési Centrum

A beszélgetést indító előadások különböző fókuszból elemezték a szakképzési törvény elmúlt 25 évét, a történeti és nemzetközi kitekintés mellett felhívták a figyelmet a ma problémáira, fejlesztési javaslatokat is meg fogalmaztak. A panelbeszélgetésen 12-16 fő vett részt az előadókon kívül, folyamatos cserével. A bevezető előadások rövid tartami összegzése:

Lükö István: Nemzetközi kitekintés az első szakképzési törvény korszakáról

Adatokkal alátámasztva vizsgálhattuk azt a nemzetközi környezetet, amely keretében megfogalmazódott a magyar szakképzési törvény, az előadás kitért az európai szakképzési modellekre, a magyar szakképzés illeszkedési pontjainak bemutatásával, továbbá a magyar társadalmi viszonyokra, amelyben a rendszerváltást követően meg kellett valósítani az új szakképzést. Összegezve elmondható, hogy a magyar szakképzési törvény a régiónkban előremutató korszerű szakképzés alapjait rakta le.

Sum István, vezérigazgató SZTÁV Budapest: A szakképzési rendszer változásának hatása a felnőttek képzésére

Az előadás párhuzamba rakta az első és a mostani törvényi szerkezetet, kiemelte a felnőttképzés helyzetét. Vizsgálta az iskolai rendszerű szakképzés és a felnőttképzés kapcsolatát, az OKJ, vizsgakövetelmények és szakmai vizsga aspektusából.

Králik Tibor: A magyar szakképzés tartalmi, képzés - és intézmény szerkezeti változásai az európai képzési modellek tükrében

A tartalmi szabályozás elveit mutatta be, amely során kitért az angol kompetenciaalapú, moduláris szakképzési rendszerre. A duális képzés értelmezési változásait áttekintette és a duális szakképzés értelmezését német kontextusba helyezve mutatta be. Részletesen szólt az európai és magyar szakképzési intézményrendszer integrációs törekvéseiről.

Pagonyné Mezősi Marietta mérnöktanár, Szombathelyi Műszaki Szakképzési Centrum Hefele Menyhért Építő-és Faipari Szakgimnáziuma és Szakközépiskolája: A szakképzés tartalmi változásai és megvalósítása 1993-tól napjainkig

Az elmúlt 25 év szakképzésének tartalmi elemeiből érdemes pozitívumként kiemelni a moduláris rendszerű OKJ-t, a modul térkép megszületését, a munkatevékenységből kiinduló kompetencia alapú moduláris oktatás bevezetését. Figyelemre méltóak a korábbi időszakban bevezetett szakma tanulását elősegítő programok, a munkatevékenységekre irányuló tananyag tartalmak, tevékenységek, az ezekhez szükséges tudás megszerzésére, a képességek és készségek fejlesztésére irányuló törekvések. 
A duális képzés három alappillérére épülő gyakorlati képzés megvalósítása megfontolásra javasolt. Az iskolai tanműhely, a képzőhely és a kiegyenlítő (egalizáló) tanműhely egészséges egységében való gondolkodása fontos kérdés. Különös tekintettel érdemes figyelembe venni az ágazati specialitásokat, az egymástól eltérő szakmák sajátos helyzetét. A gyakorlati képzésben a kizárólagosan a tanulókkal foglalkozó oktatói szerep vállalás megkerülhetetlen. A szakképzés csak és kizárólag akkor lehet hatékony és eredményes, ha azt szilárd alapokra építve szakszerūen végzik, és az abban érdekelt minden fél összehangolt együttgondolkodásán és együttmúködésén alapszik.

Gubán Gyula: Szakképzésfejlesztés a 90-es években

Az előadás bemutatta a tananyagformálás elvi és gyakorlati modelljeit, kiemelve a Világbanki és a Phare programokat, az elmúlt években megvalósuló hazai szakképzési fejlesztéséket és azok célrendszerét. Elemzésében kitér azokra az eredményekre, ami a mai szakképzés fejlesztéséhez is tapasztalattal szolgálhatnak. Javaslatai különösen a szakmai tanárképzés számára hasznosak és fontosak.

\section{Az elöadók és hozzászólások az alábbi javaslatokat fogalmazták meg:}

1. Szakképzési tartalom változása: technológiák, eszközök, eljárások oktatása helyett kompetenciafejlesztés, szakképzési alapkompetenciák fejlesztése (anyanyelvi kommunikáció, matematika, természet- és múszaki tudományok, digitális kompetencia, idegen nyelv) és a munkavállalói kompetenciák irányába kell elmozdulni. Ez alapvető módszertani változást igényel amelyre fel kell készíteni a tanárokat és a szakoktatókat, a szakmai-pedagógus képzésnek is ebben az irányban kell megújulnia. A gyakorlati oktatásban nagy hangsúlyt kell fektetni a projektoktatás módszertanára.

2. A szakképzés 25 éves történetében nagyszabású és eredményes szakképzés fejlesztési projektek (PHARE, világbanki, SZFP I-II., TÁMOP) valósultak meg, ezek eredményeire és tapasztalataira támaszkodva kell ma tovább lépni.

3. A német szakképzési modell alapján nálunk is célszerű szétválasztani mind a tartalmi szabályozás, mind a szervezés, mind a duális képzés megvalósítása terén a nagyipari és kisipari szakképzéseket.

4. Célszerű a kamarai hatáskörök tisztázása, a tartalmi szabályozásban a kamara a "mi” területén határozza meg a tartalmat, a miért és hogyan, stb. kérdésekhez komoly szakmai és tudományos támogatást szükséges adni.

5. A német duális képzés mintájára le kellene írni szakmánként, hogy milyen feltételek szükségesek a gyakorlati tanmúhelyhez és a gyakorlati munkahelyhez, mint szükséges feltétel-rendszer.(épület/helyiség kialakítás, munkahelyek kialakítása, szociális részek szerszámok, eszközök, IKT támogatottság, személyi feltételek). Ennek a standardizált követelményeknek kell megfelelni az ellenőrzés során.

6. Forrást szükséges teremteni az iskolai tanmúhelyek technológiai színvonalának biztosítására, a gyakorlati alapképzés jelentős része, támogatandó módon továbbra is ezekben a mühelyekben folyik.

7. Aránytalan a gimnáziumban és a szakképzésben továbbtanulók aránya, javasoljuk a pozitív ösztönzést a szakképzés irányába:

a) A 8. osztály második félévében a szakképzési alapkompetenciákból (anyanyelvi kommunikáció, matematika, természet- és műszaki tudományok, digitális kompetencia, idegen nyelv) mérést kell végezni, akik nem érnek el egy a szakképzésbe való 
bekapcsolódási szintet, azok 1+3 éves szakközépiskolai képzésben folytathatják tanulmányaikat. Ebben az új egy évben alapkompetencia fejlesztés (más módszertannal) és pályaorientáció alapozná meg a szakképzésbe való bekapcsolódás lehetőségét. Egy-két év után ez visszahatva pozitívan befolyásolná az általános iskolákból kikerülők tudásszintjét.

b) Szükség van a szakképző iskolák épületeinek, infrastruktúrájának számottevő javítására, vonzóvá kell tenni ezeket az intézményeket.

c) A teljes szakképzésben ösztöndíjat kell bevezetni, magasabb szinten mint most, a minimálbér feléhez közelítve.

8. Pályaválasztást későbbi időpontba kell tolni, a szülők nehezen vállalják fel, hogy 14 éves korban a gyermekükre vonatkozóan alapvető irányról döntsenek, ehhez rugalmasabb iskolaszerkezet (szakgimnázium szakközépiskola) szükséges.

a) Szakgimnáziumban a 4+1 éves modell jó, tantervi átcsoportosítással és tartalmi felülvizsgálattal (szakmai kompetenciák irányába való elmozdulás) a 9-10 évfolyamon közel azonos tantervet, 11-12. évfolyamon ágazati közös taratalmat, 13. évfolyamon szakképesítésnek megfelelő specializációt kell oktatni. Ezzel a szakmai irányok közötti átjárás és rövidebb idejü új szakképesítés megszerzése is biztosítható. Összességében ez kitolja a konkrét szakmaválasztás időpontját.

b) Szakközépiskolában az 1+3 éves modell lehetővé tenné, hogy a 9. osztályban az alapkompetencia fejlesztéssel és pályaorientációval a 3 éves közismereti oktatás óraszámának csökkentésével lehetővé válna a szakmai tárgyak (elmélet, gyakorlat) erősítése, a vállalkozói ismeret és a digitális tudás fejlesztése.

9. A most pályázati forrásból múködő gyakornoki támogatást rendszerszinten szükséges múködtetni és össze kell kapcsolni a tanulószerződés intézményével, Érje meg tanulót képezni és utána támogatással alkalmazni. Ez biztosítaná a „képzés befejezését munkavállalóként", amely az adott vállalati technológiába való betanulást is támogatná.

10. A duális szakképzés jogi és szakmai értelmezését pontosítani szükséges, ma jogszabályokban ez a tanulószerződéses képzést jelenti. Célszerú a német fogalmat és gyakorlatot alkalmazni, ahol ez inkább elméleti képzést és ehhez kapcsolódó alapozó gyakorlatot jelent és ehhez kapcsolódik a vállalati képzés, amely nem csak gyakorlatot tartalmaz, sok esetben ad elméleti ismereteket is.

11. A felnőttképzés elmozdult az OKJ-s képzések irányába, a kötelező idejű képzések gátat jelentenek jelenleg, fontos lenne a vállalati részképzések és rövid idejű felnőttképzések, vállalati saját dolgozók képzésének támogatása.

12. A felnőttoktatás szerepe erősítendő, az OKJ-s képzések így mindenki számára hozzáférhetők, ennek munkaerőt mobilizáló hatása van.

13. Az OKJ szakképzés számát csökkenteni szükséges a német példa alapján. Ezzel visszaadva a nem OKJ-s képzések munkaerőpiaci jelentőségét.

14. A felnőttképzési törvény tartalmi része kerüljön be a szakképzési törvénybe, a mostani tartalom az eljárásrendbeli szabályozások a rendeletekben legyenek szabályozva.

Panelvezetői összegezés (Lükő István)

Az eredeti elképzelés és megfogalmazás szerint jól teljesítettük a vállalásunkat. Szerencsés volt az előadók kiválasztása, mert minden részterületről kompetens, nagy tapasztalattal rendelkező kolléga mondta el egyrészt múltbeli tényszerű ismereteit. Másrészt kicsit a jelennel és a jövővel is 
foglalkoztak. A személyes kötődések, szubjektív élmények hitelessé tették és élénkítették a tartalmi kifejtéseket. Nem kevésbé volt szerencsés Králik Tibor raportőri kiválasztása és felkérése, aki nagyon jól irányította a panel előadóinak, jelenlévőinek a kapcsolódásait, a rövid tartalmi ismertetőt stb. Nagyon jól kamatoztatta felkészültségét, beosztotti és többszintű vezetői tapasztalatait, kapcsolatrendszeréből eredő tájékozottságát.

Egyetlen egy téren tért el a panel program a tervezettől, az pedig az időtartam, illetve időbeosztás. A beszélgetésre kevesebb idő maradt a tervezettnél. Az öt előadás közül egyedül Pagonyné Mezősi Marietta tartotta be az időkeretét, ugyanakkor nem maradt hiányérzet emiatt, mert a korábbi előadók által említett részeket kihagyta. Ezt önkritikusan be kell vallanom, de nem bánom abból a szempontból, hogy a jelenlévők nagyobb mélységben és szélesebb aspektusokat érintve mutatták be a szakképzési törvény és a hozzá kapcsolódó rendelkezések, szabályozások kapcsolódását és különböző hatásait. A jelenlévők közül többen is aktív, meghatározó résztvevői voltak egy-egy területnek. Előkerültek pl. a DACUM táblát először alkalmazók, fejlesztők tapasztalatai, a szakmai tanárképzés különböző kapcsolódásai, a felnőttoktatás intézményrendszerének változásait megélők egyetértő és segítő szándékú javaslattételei is

\section{A képzési struktúrák alakulása. Hogyan tovább szakképzés?}

Raportöri beszámoló az 2. panelbeszélgetés munkájáról (összeállította: Schindler Rózsa)

A legnagyobb érdeklődést kiváltó (82 fős) panel arra vállalkozott, hogy megvitassa a nehéz helyzetbe került szakképzés rendszerét, mélyreható átgondolt tartalmi és szerkezeti változásokra tegyen javaslatot a szakma részvételével. Elvárás volt, hogy olyan szakképzési modellt kell vizionálni, amelynek meg kell felelnie a 21. század kihívásainak, mely a fiatalokat felkészíti a folyamatos gazdasági változásokra és a folyamatos tanulási igény iránti elkötelezettségre, hisz a ma fiataljai 2060-ban is aktív részesei lesznek a munkaerőpiacnak. Ezért a panel a szakképzési szerkezet, szakképző intézménytípusok, szakmastruktúra, vizsgarendszer a szakképzésben, szakmai pedagógusképzés, átjárhatóság és a zsákutcamentes képzés kulcsszavak mentén dolgozta fel a címben megfogalmazott széles szakmai tartalmat.

A panel bevezető előadásai:

Palotás József (elnök, Felnőttképzési Szakértők Országos Egyesület):

A szakképzési szerkezet negyed százada - az elókészitő és alapozó oktatástól a szakgimnáziumig

A vitaindító célja a szakképzés szerkezetével, a szakmastruktúrával és a tartalomszabályozással kapcsolatos szakmai diskurzus megalapozása volt. A szakképzés szerkezete, a szakmastruktúra, valamint a tartalomszabályozás számos változáson ment keresztül az elmúlt negyed században. Az átalakítások gyakoriságát a rendszer szereplői olykor nehezen követték, a döntések indokoltságáról és helyes irányáról szakmai viták, diskurzusok folytak és folynak ma is.

A vitaindító előadásban a szakiskolai és szakközépiskolai (szakgimnáziumi) képzési szerkezet változásainak vázlatos áttekintéséről kaptunk tájékoztatást a rendszerváltást követő szakképzési törvény megalkotásától napjainkig. Számos fogalmat sorra vett a visszatekintés, mint a szakmai előkészítő és a szakmai alapozó oktatás, a szakmai orientáció és a szakmacsoportos alapozó oktatás, az „előrehozott” szakképzés, az „ágazati” szakközépiskola, szakgimnázium. Az áttekintés a szabályozásból és annak módosításaiból indult ki, elősegítendő a témában a szakmai diskurzus 
megkezdését. A vitaindító egy olyan középfokú szakképzési modell-javaslat generálását célozta meg, mely az eddigi törekvések eredményeit, értékeit integrálva - okulva azok hibáiból, hiányosságaiból a tanulók egyéni képességeinek kibontakoztatását, a vertikális és horizontális átjárhatóságot, a hátránykompenzációt és tehetségfejlesztést, valamint a munkaerőpiacnak adekvát kimenetet, a továbbtanulás lehetőségét egyaránt igyekszik biztosítani. Szándékunk szerint a gyakori változások tapasztalatai megalapozhatnak egy széles szakmai konszenzust élvező, hosszabb kifutású javaslatot a jövőre nézve.

Király László (igazgató, Budapesti Múszaki Szakképzési Centrum Bolyai János Múszaki Szakgimnáziuma és Kollégium, az Oktatási Hivatal Bázisintézménye):

A munkaerő piaci elvárások teljesítésének lehetőségei az állami fenntartású szakképző intézmények területén

Az előadás célja a szakképzési centrum szervezeti keretei között múködő nagy múltú iskolakomplexum szakmai-tartalmi lehetőségeinek bemutatása a gazdasági elvárások függvényében és az iskola megtartó erejének növelésére tett kísérlet bemutatása. A témaválasztást előzményének bemutatására az előadó saját esettanulmányával vállalkozott: „... a 2017/18-as tanév előkészítése kapcsán intézményvezetőként azzal a problémával kellett szembesülnöm, kezdte az előadó, hogy a betöltetlen informatika tanári álláshely(ek) ellátatlan órákat eredményeztek, és ez a körülmény alapvetően veszélyeztette a tanévkezdést. Ezért született az a döntés, hogy a legnagyobb óraszámban hiányzó informatikai szakmák képzéséhez szükséges gyakorlati órák megtartását tanulószerződés keretében, külső gyakorló helyre szervezzék ki egy gyakorlati órák szervezésével foglalkozó vállalkozás közremúködésével."

Látszólag a vállalkozásnak rendelkezésére álltak a gyakorlati oktatás tárgyi és személyi feltételei, de a tartalmi kérdésekkel már problémái voltak. A „mit tanítsunk”- kérdés megválaszolásához az SZVK és a kerettanterv, mint alapanyag mellé gyakorlati feladatokkal is segítették a munka megkezdését. A vállalkozás felkészületlensége néhány hónap után világossá vált, ezért a sikeres vizsgafelkészítés érdekében az iskola belső erőforrásainak átszervezése után a tanév második félévétől vissza kellett vinni az iskolába a technikus osztály gyakorlati foglalkozásait. Ez a lépés adminisztratív oldalról azt jelentette, hogy a tanulók, kamara és képző vállalkozás között létrejött tanulószerződést fel kellett bontaniuk, ami értelemszerūen anyagi és presztízs veszteséget jelentett a képző cégnek. Kárenyhítésként a cég képviselői azzal védekeztek, hogy informatikai cégek részéről lett volna igény és lehetőség a tanulók alkalmazására a gyakorlati képzés keretében,de a tanulók nem éltek vele. Ennél a pontnál felmerülhet néhány alapvető kérdés:

- Az iskolai rendszerú szakképzés esetén mi az alapvető feladata, felelőssége a képzést szervező intézménynek?

- Milyen mértékben, milyen tartalommal várható el a szakképzés folyamatában résztvevő tanulóktól, hogy a szorgalmi időben bekapcsolódjanak egy cég szakmai tevékenységébe?

A szakképzés szereplőinek tevékenységét meghatározó alapelvet megtalálhatjuk a „2011. évi CLXXXVII. Törvény a szakképzésről” törvény Általános rendelkezéseket taglaló részében.

I. Fejezet Alapelvek 1. § (7) Az iskolai rendszerü szakképzés feladata a komplex szakmai vizsgára történő felkészítésen kivül az életben való sikeres boldogulásra történő felkészités és a tanuló életkori sajátosságához igazodó nevelés is. 
A szakképzés folyamatát meghatározó dokumentumokról:

A szakképzés kereteit meghatározó tartalmi szabályozók vázlatos bemutatásával érzékeltette a rendszer komplexitását, a dokumentumok egymásra épülését.

Országos Képzési Jegyzék (OKJ) tartalmi elemek:

- A képzés szintje, tanulmányi területe

- Szakképesítés megnevezése

- Szakmacsoport

- Ágazati besorolás

- Iskolai-rendszerū képzési idő

- Iskolarendszeren kívüli képzési idő

- A képzés munkarendje

- MKKR szint

- A szakképesítésért felelős miniszter megnevezése

Szakmai követelménymodul tartalmi elemei:

- Feladatprofil:

- Tulajdonságprofil:

- Szakmai kompetenciák, szakmai ismeretek

- Személyes kompetenciák

- Társas kompetenciák

- Módszerkompetenciák

Szakmai és vizsgakövetelmények (SZVK),Szakképzési kerettantervek. Tartalmi elemek:

- A szakképzés jogi háttere

- A szakképesítés alapadatai

- A szakképzésbe történő belépés feltételei

- A szakképzés szervezésének feltételei

- A szakképesítés óraterve nappali rendszerū oktatásra

- Szakmai követelménymodul tantárgyai, témakörei

Lehetőség a munkaerőpiaci szereplők elvárásainak közvetlen megismerésére

A szakképzés területén komoly segítséget jelentenek azok a szervezetek, amelyek hídszerepet töltenek be az intézmények és gazdaság szereplői között. Jó példa erre az informatika szakmacsoportos szakképzés tartalmi és szervezeti mentorálását végző http Alapítvány tevékenysége, amely az informatikai szakmák oktatásához korszerű tananyagok eljuttatásával, szakmai tanártovábbképzés és konferenciák szervezésével komoly segítséget nyújt a szakképző intézményeknek.2018-ban is megszervezték a Legyél Te is Informatikus! - Informatikai Oktatási Konferenciát, amely alkalmat adott arra, hogy az informatikai cégek képviselői találkozzanak az oktatás, a szakképzés képviselóivel. Ezen a konferencián hangzott el a „Milyen pályakezdő informatikusra van szüksége a szakmának?" címú előadás is, amely vázolta, hogy jelenleg milyen elvárásai vannak a gazdaság szereplőinek.

Jó gyakorlat bemutatása: Szakmai életpálya-épités napja

Minden tanévben különlegesen fontos időszak a február 15-i érettségi és továbbtanulási jelentkezési határidő. Elsősorban végzős diákok számára, de tapasztalatszerzés céljából valamennyi diák részvételével megszervezi az iskola a Szakmai életpálya-építő napot, melyre a gazdaság különböző 
szereplőit, cégek, egyetemek, főiskolák képviselőit hívjuk meg abból a célból, hogy az iskola diákjai közvetlenül, első kézből értesüljenek a munka világának illetve a továbbtanulás lehetőségről.

A témakör feldolgozásának zárógondolatában ismét a 2011. évi CLXXXVII. Törvény a szakképzésröl című törvény Első részének az Általános rendelkezésekre hivatkozott az előadó.

I. Fejezet Alapelvek

1. § (3) A szakképzés e törvény hatálya alá tartozó szereplői (különösen a tanuló, aszülö, a szakképzést folytató intézmény, a gazdálkodó szervezet és a gazdasági kamara) a szakképzési feladatok megvalósítása során kötelesek egymással együttmüködni.

A napi gyakorlatot bemutató előadás választ próbált adni arra, hogy

- az iskolapadból kikerülő, a munka világába munkavállalóként jelentkező pályakezdő szakemberekkel szemben milyen elvárásokat támaszt a fogadó gazdaság, és erre az elvárásra miként tudja felkészíteni a szakképzés területén működő intézmény,

- a szakképzés jogszabályi háttérrel alátámasztott tartalmi szabályozásai és a munkaerőpiaci szereplők aktuális elvárásai közötti összhang megteremtésének, mik a lehetőségei az elmúlt időszak változásainak tükrében.

\section{Molnár György (főigazgató, BME Tanárképző Központ)}

A szakképzési igényeknek megfelelő szakmai pedagógusképzés - realitás vagy utópia?

Az előadás célja szakmai pedagógusképzés, foglalkoztathatóság, átjárhatóság, lehetséges tanulási utak bemutatása volt a szakképzés erőforrás-támogatása céljából. Szándéka volt továbbá bemutatni a szakmai pedagógusképzés típusaiban, struktúrájában, a szakok és szakirányok rendszerében végbement változásokat, a szakmai pedagógusképzés szakképzés rendszeréhez való illeszkedést, illetve a konzisztencia problémákat, valamint a szakmai pedagógusok foglalkoztatásával kapcsolatos problémákat, a foglalkoztathatóságot szolgáló tevékenységekre szóló javaslatainkat. A témával való foglalkozás aktualitását elsősorban a szakképzés-, és a szakmai pedagógusképzés rendszerében 2010től végbement változások indokolják.

A szakmai pedagógusképzés körébe soroljuk a szakmai tanárképzést és a szakoktató képzést. A szakmai tanárképzés „klasszikus” képzései elsősorban a mérnöktanár, a közgazdásztanár és az agrármérnök-tanár szakon folyó képzések. Ezek hagyományos képzési formái korábbról úgy ismertek, mint „másoddiplomás” vagy „kiegészítő” képzések. Jellemzőjük, hogy a már megszerzett főiskolai vagy egyetemi szakterületi diploma birtokában lehetett a képzésre jelentkezni, mely az osztott tanátképzési formát jelenti.

Napjaink szakmai tanárképzésének körébe tartozik a mérnök-, a közgazdász-, és az agrármérnöktanárképzés mellett a gyógypedagógia-tanár, az egészségügyi-, a konduktor-, és a pedagógiatanár tanárképzés. Ezek képzési célja: „az iskolai nevelés-oktatás szakképesítés megszerzésére felkészítő szakaszainak évfolyamain, az iskolai rendszerű, illetve az iskolarendszeren kívüli szakiskolai, szakközépiskolai oktatásban, felnőttek át- és továbbképzésében, továbbá az Országos Képzési Jegyzékben meghatározott szakképzésekben adott szaktárgyak tanítására való felkészítés. A végzett szakmai tanárok és szakoktatók potenciális munkaerőpiacát a szakképzés intézményrendszere adja, így nagyon fontos lenne az államilag elismert szakképesítések (OKJ) szaktárgyainak tanítására felkészült tanárok szakképzési tantárgyi igényekhez illeszkedő foglalkoztatásának biztosítása. 
A BME Múszaki Pedagógia Tanszék szerepe a pedagógus továbbképzésben hosszú évek óta kiemelkedő, eredete immár 147 évre tekint vissza. Küldetésnyilatkozatát 1870 Báró Eötvös József vallás- és közoktatásügyi miniszter leveléhez datálhatjuk, amelyben megírta, hogy az 1871-ben létrejött Múegyetemen tanárképezdét kell felállítani. Ezt tekintjük a mérnöktanárképzés jogelőd alapjának. Ennek értelmében a konferencia helyszínét is biztosító egyetemünkön, már hosszú ideje folyik a szakmai tanárképzés valamely formája. Ennek birtokában lehetőségünk van arra, hogy helyzetelemzést végezzünk a szakmai pedagógusképző és a szakmai pedagógusokat foglalkoztató intézmények együttmúködési kapcsolatrendszerére és az együttmúködés területeire vonatkozóan. Emellett vizsgáltuk a szakmai pedagógusképzést folytató felsőoktatási intézmények szak-szakirány szerint differenciált képzési kínálatát, a képzésekre jelentkező hallgatói létszámokat, a szakképző intézményekből a BME-re felvett hallgatók szakmai tanári szakirány szerinti megoszlását, a képzésben résztvevőket támogató szakképző intézmények szakképzési tantárgyi tanárigényeit.

Az OKJ változásaiból eredő szakmai tanári képesítési igényeknek való megfeleltethetőség számos kérdést vet fel nem csak a képzők, hanem a szakképző intézmények oldaláról nézve is. Időközben a változásokat kezelve az egyetem képzési portfóliójának bővítése is folyamatos céllá vált. Mindezek mellett, mint országos szinten a legnagyobb szakmai tanárképző bázisként, központként, egyfelől alkalmazkodunk a digitális kor pedagógiai kihívásaihoz a korszerű, atipikus tanítási módszerek és tanulási formák bevezetésével és alkalmazásával, másfelől a szakmai tantárgyi tartalmak folyamatos megújításával kooperatív módon bevonjuk és aktivizáljuk a szakmai tanárokat és a diákokat is egyaránt. Ehhez kínálunk mikrotartalom-alapú digitális nyitott tananyag-fejlesztési megoldásokat a szakképzés számára.

Szenes György (elnök, MPT Szakképzési Kollégium): A középfokú szakképzés kívánatos fejlesztési iránya (az előadó gondolatait bővebben is kifejtette, melyet tematikus számunk Tanulmányok rovatában közlünk).

Kihívások és lehetőségek a szakképzésben - A munka alapú tanulás elméletétől a szakképzés napi valóságáig

Raportôri beszámoló az 3. panelbeszélgetés munkájáról (összeállította: Hegyi halmos Nóra és Kraiciné Szokoly Mária)

A panelbeszélgetés mintegy 60 fős hallgatóság érdeklődésétől kísérve, jó hangulatban végezte munkáját. Célja volt, hogy a szakképzés világában egyre gyakoribbá váló fogalmakat és jelenségeket értelmezze, összehozza és beszélgetésre ösztönözze a szakképzésben kutatással, a gyermek és felnőtt tanulók toborzásával és képzésével foglalkozó szakembereket. Így kapott helyet a felvezető, gondolatébresztő előadások sorában két egyetemi oktató, egy oktatáskutató, valamint az egyik budapesti szakképzési centrum igazgatója, aki a szakképzés gyakorlat oldalának problémakörével gazdagította a beszélgetést. A problémafelvetések sorát az EPALE program képviselője zárta, ismertetve az Európai Tanács által indított „Új lehetőségek felnőttek számára” címú programot.

Európai uniós elvek és a szakképzés magyar gyakorlata címmel a 3. panelbeszélgetést Kraiciné Szokoly Mária nyitotta meg. A LLL eszményének mérlege címmel egy összefoglaló ábrán elemezte a lifelong learning eszményének és megvalósulásának helyzetét napjainkban. 
A LLL eszményének mérlege

\begin{tabular}{|c|c|}
\hline A Vízıó & A VALÓSÁG \\
\hline $\begin{array}{l}\text { - Középpontban a TUDÁS és az EMBER, } \\
\text { - Növekvő JÓLÉT } \\
\text { - } \quad \text { A tudástársadalomban a képzés révén a világ } \\
\text { problémái (pl. előítéletek, diszkrimináció, } \\
\text { munkanélküliség, éhezés stb.) megoldhatók. } \\
\text { - TUDÁSTÁRSADALOM } 2010 \text { és 2020, } \\
\text { - Egyénre szabott, KOMPETENCIA ALAPÚ } \\
\text { KÉPZÉS } \\
\text { - Tudásmenedzsment, TANULÓ SZERVEZETEK, } \\
\text { tanuló régiók, városok } \\
\text { - FELZÁRKÓZÓ HÁTRÁNYOS HELYZETÚ } \\
\text { TÁRSADALMI CSOPORTOK } \\
\text { - NÖVEKVŐ FOGLALKOZTATÁS } \\
\text { - Oktatás és gazdaság ÖSSZefonódása }\end{array}$ & $\begin{array}{l}\text { - Középpontban a GAZDASÁG és a politika } \\
\text { érdeke } \\
\text { - Növekvő SZEGÉNYSÉG } \\
\text { - A KÉPZÉSEK, felzárkóztató projektek } \\
\text { HATÁSA, eredményessége ALIG ÉRZÉKELHETŐ. } \\
\text { - európai szintű készség- és ismerethiány, } \\
\text { FUNKCIONÁLIS ANALFABÉTIZMUS, a PISA sokk, } \\
\text { - Az oktatási reformok nem hoztak átütő } \\
\text { eredményeket, korai iskolaelhagyás } \\
\text { - LESZAKADÓ TÁRSADALMI CSOPORTOK } \\
\text { - NÖVEKVŐ MUNKAERŐHIÁNY } \\
\text { - Motiválatlan fiatalok a szakképzésben } \\
\text { - Oktatás és gazdaság távolsága nem csökken }\end{array}$ \\
\hline
\end{tabular}

Az előadó megállapította, hogy az ezredfordulót megelőzően a gazdasági fejlődés kulcselemeként került reflektorfénybe az élethosszig tartó tanulás elve, amely új paradigmaként a tanulót és a tanulást, a állította az gyakorlatközpontú, a gazdaság érdekei által vezérelt oktatási-képzés középpontjába. Kezdetben az Unió és a tagországok egyaránt nagy reményeket fúztek a LLL megvalósulásához, azonban napjainkra elv megvalósulásának reménye elhalványult. Megjelent az élethosszig tartó tanulás politika új generációja, az OECD által bevezetett képesség stratégia, amely paradigmatikus gondolkodásmód-váltást jelentett, azzal, s a kvalifikációval szemben a képességek használatára (skills) helyezte a hangsúlyt. Ezzel párhuzamosa új hatékonyságnövelő tényezőként jelenik meg munkahelyi szinten a tudással és képességekkel való tudatos gazdálkodás, a tudásmenedzsment és az innováció területe. Egyre nagyobb jelentőségű a munka alapú és a munkahelyi környezetben folyó tanulásnak, felértékelődik oktatás és felhasználói, a gazdaság, aktorai közötti intenzív együttműködés jelentősége, különös tekintettel a szakképzés területén nagy számban megjelenő hátrányos helyzetű, alulképzett társadalmi csoportok képzésének korszerúsítésére. Eurostat adatok alapján beszélt a magyarországi felnőttképzésben résztvevők arányának alacsony voltáról, mint a szúkös munkaerőpiaci kínálat gazdasági fejlődést hátráltató voltáról.

Kereszty Orsolya „A munka alapú tanulás aktuális kérdései” címú előadásában a felnőttképzés és szakképzés kutatás új irányairól szólt, friss kutatási eredmény bemutatásával. Megállapította, hogy számos empirikus kutatás foglalkozik a tanuló szervezet - tanulót támogató szervezet - tanulás központú szervezetek mibenlétével, a munkahelyi tanulással. Kutatott témává válik lassan a munkahelyi tanulás értelmezése. Ehhez járul hozzá az Adult Education Survey (AES 2011); a Continuing Vocational Training Survey (CVTS 2010), a vállalkozások képzési tevékenységének vizsgálata.

A tudásalapú társadalomban alapvető kérdés, hogy milyen mértékben tudnak saját tudást létrehozni a tudást szervezetek, és azt hogyan tudják menedzselni, hozzáférhetővé tenni, fejleszteni, melynek meghatározó része, hogy milyen módon gondolkodnak a kevésbé mérhető informális tanulásról. 
Az előadás érintette a munkahelyi tanulás fogalmának aktuális értelmezéseit: a humán- erőforráspolitika és a képzési rendszer, az innovációban való részvétel, a munka közben kínálkozó tanulási lehetőségek, a dolgozók tanulási motivációja és a munkakörnyezet kérdésköreit (CEDEFOP, 2011). Az előadó megállapította, hogy viszonylagos az egyetértés abban, hogy mekkora szerepe van a munkafeladatoknak és a munkakörnyezetnek abban a kérdésben, hogy mit és hogyan tanulhat az ember munkavégzés során érintve Nieuwenhuis-Van Woerkom (2007) és Kooken (2007) értelmezéseit, akik szerint a tanulás a munka mellékterméke .

Végezetül felhívta a figyelmet arra, hogy a kutatások fontosak abból a szempontból is, hogy ráirányítják a figyelmet egy-egy problémára, amelyek hatással lehetnek a szakpolitikusokra és a döntéshozókra. Ilyen új kihívást jelentő témák $X, Y, Z$ generációk megjelenése a munkahelyeken, aZ élményalapúság fontossága a tanulásban és a munkában, az IKT eszközök és a távmunka elöretörése, a home office megjelenése, a munkához kapcsolódó tanulás gazdagodó jelenségvilága.

Derényi András problémafelvető előadásában a szakképzés fejlesztésének nézőpontjából a képesítési keretrendszerekben rejlő lehetőségekről szólt. Összehasonlította az európai és hazai képesítési keretrendszerek eredeti céljait, ambícióit, és jelenlegi aktuális eredményeit, bemutatta a rendelkezésre álló egyre több, a képességpolitikák implementálását támogató nemzetközi eszközt. Az EKKR és az MKKR eredeti céljairól és a megvalósulás eredményeiről, illetve eredménytelenségeiről szólva beszélt az oktatási alszektorok feletti áthidaló funkcióról, az alszektorok szabályzóinak és képesítéseinek lassú konvergenciájáról. Kommunikációs eredménynek tekinthető szerinte a kimenetvezéreltség elvének jobb megértése, a tanulási eredmény alapú képesítés-tervezés lassan-lassan megvalósuló elterjedése.

Az EKKR és az MKKR eredeti céljainak megvalósulása kapcsán megállapította, hogy az alszektorok irányítói és a képesítésgazdák közötti tapasztalat megosztás elmaradt, a túlszabályozottság miatt nehéz a folyamatok, szabályozások továbbvitele. A keretrendszerhez kapcsolódó validáció kapcsán megállapította, hogy nincs látható validációs tevékenység hazánkban, az egyszerre alul- és túlszabályozottság gátolja a validációs gyakorlatok kialakulását. Végezetül az alszektorok közötti együttműködésről, mint a szakképzés fejlesztésének egyik lehetséges útjáról beszélt, kiemelve az alulról jövő kezdeményezések, az alszektorok közti együttműködések, a közös fejlesztések, az egymástól tanulás, a tapasztalat megosztásának fontosságát. A nagyobb figyelem fordítását a fejlesztési, besorolási, illesztési, elismerési stb. módszertanok, minőségbiztosítási elvek összehangolására, a stakeholderek érdekeltségeinek azonosítása, ennek mentén közös cselekvési terek kialakítására. (Teljes előadása e tematikus szám Tanulmányok rovatában olvasható.)

Valló Péter, a Budapesti Komplex Szakképzési Centrum (BKSZC) igazgatója szabad előadásában a szakképzés napi kihívásairól beszélt a szakképzési centrumok nézőpontjából. A képzési intézményrendszer és a jogszabályi környezet gyors változásainak problémái mellett fő nehézségként az iskolarendszerű szakképzésben a csökkenő tanuló létszámot említette elsőként, azt a tényt, hogy a felnőttoktatás húzza fel a képzési létszámokat. Megemlítette továbbá azt a fontos tényt, hogy a szakmaválasztásban nem elérhető, hogy a tanulók a hiányszakmákat válasszák, nincs a munkaerőpiacon oly keresett szakmákra jelentkező, mint az ács, ugyanakkor a szolgáltató szakmákban (fodrász, kozmetika) igen erős a túljelentkezés. Kiemelendő nehézségként említi a szakoktató hiányt, amely alapjaiban teszi nehézzé, olykor majdnem működésképtelenné a 
szakképzést számos területen (kárpitos). Kiemelte továbbá a szakképzést fő nehezítő tényezőjeként, hogy jelentős készség-képesség hiányos és alulmotivált gyermek érkezik az oktatás ezen szintjére. A szakképzés önmaga megoldani nem képes ezeket a problémákat. Megállapította, hogy a jelen helyzetben nincs más lehetőség, mint: különböző módszerekkel-programokkal segíteni a tanulókat. A BKSZC felmérésekre alapozott intézkedési tervek kidolgozásával és megvalósításával igyekeznek úrrá lenni a nehéz helyzeten. További nagy probléma, hogy egyre hátrányosabb élethelyzetből érkeznek a tanulók. Az alacsony előképzettségú, elmaradt szociokulturális környezetből jövő tanulók alapvető higiénés szokásokkal sincsenek tisztában. Szövegértésük gyenge, ami nélkül pedig a nagy értékű gépek közelébe sem engedhetők.

Javaslatként fogalmazta meg: olyan felnőttképzések és a rövid képzések arányának növelését, amelyek gyorsabb választ adnak a munkaerőpiac igényeire. Fontos lenne az intenzívebb párbeszéd a kamarákkal, szakszervezetekkel, munkaadókkal, továbbá a szervezetfejlesztés továbbá az uniós források jobb felhasználása (módszertan, infrastruktúra stb.), a pedagógusok módszertani fejlesztése, a tudásmenedzsment elterjedése, azaz a kollégák közötti munkahelyi tanulás, fejlődés, fejlesztés előmozdítása.

A Budapesti Komplex Szakképzési Centrum iskoláiban a hátrányok leküzdésére, a motiváció növelésére a Komplex Instrukció Programot alkalmazza, melynek lényege, hogy minden gyerek tudásszintje emelkedjen, és része legyen sikerélményben az osztálymunka során. A KIP lehetővé teszi a tanárok számára a magas szintű csoportmunka szervezését olyan osztályokban, ahol a tanulók tudása és kifejezőkészsége nagy különbségeket mutat. Az osztályon belüli státuszbeli problémák időben felismerhetőkké és kezelhetőkké válnak; lehetőség nyílik az együttműködési normákra történő felkészítés; sokféle, eltérő képességeket megmozgató tananyag alkalmazásával lehetséges a megbúvó képességek kibontakoztatása.

Vedovatti Anildo, az EPALE projekt koordinátora „A TANÁCS AJÁNLÁSA (2016. december 19.) a kompetenciafejlesztési pályákról: Új lehetőségek felnőttek számára” c. projekt ismertetőjében elmondta, hogy az Európai Unió tagállamainak többségében a 25-64 év közötti lakosságának több mint negyede 2015-ben legfeljebb alsó középfokú végzettség megszerzését követően kilépett az iskolarendszerű oktatásból és képzésből. Ezeknek az embereknek alapkészség szintje - az OECD PIAAC mérések alapján -, hasonló arányban egyezik meg a legalacsonyabb jártassági szinttel. A PIAAC rámutat arra, hogy azok a 16-65 év közötti felnőttek, akik az írás-olvasás-, számolás- és digitális készségterületeken alacsonyabb jártassággal rendelkeznek, kisebb valószínúséggel kezdenek tanulásba, vagy vesznek részt teljes körűen a digitális technológia által vezérelt gazdaságban és társadalomban. Az alacsonyan képzett felnőttek részvétele az egész életen át tartó tanulásban továbbra is négyszer alacsonyabb, mint a felsőfokú képesítéssel rendelkezők esetében. Őket nagyobb mértékben fenyegeti a munkanélküliség, a szegénység és a kirekesztődés lehetősége, náluk általában magasabbak az egészségügyi kockázatok és alacsonyabb a várható élettartam, valamint gyermekeik esetében nagyobb mértékben fennáll a gyengébb iskolai teljesítmény kockázata.

Az Európai „Tanács AJÁNLÁSA (2016. december 19.) a kompetenciafejlesztési pályákról: Új lehetőségek felnőttek számára" című program célja, hogy a tagállamok további rugalmas lehetőségeket biztosítsanak érintett felnőtt célcsoportjaik írás-olvasás-, számolás- és digitális kompetenciájának javítására, megerősítsék továbblépési lehetőségeiket a munkaerőpiac és az aktív 
társadalmi részvétel szempontjából fontos, magasabb európai képesítési keretrendszer (EKKR) szintjei felé $(3,4)$. A program célcsoportja a kompetenciafejlesztési pályák alacsony szintű készségekkel, ismeretekkel és kompetenciákkal rendelkező, az ifjúsági garancia keretében támogatásra nem jogosult felnőttek. A megvalósításban bevonni kívánt szereplők a nemzeti joggal és sajátosságokkal, valamint a rendelkezésre álló erőforrásokkal összhangban törekednek a program céljainak elérésére a szociális partnerekkel és az oktatási és képzési szolgáltatókkal szorosan együttmúködve.

A program végre hajtása során, amennyiben lehetséges, az alacsony képzettségú felnőttek tekintetében alkalmazzák a nem formális és az informális tanulás eredményeinek érvényesítéséről szóló, 2012. december 20-i tanácsi ajánlással összhangban kialakított érvényesítési mechanizmusokat a meglévő készségek meghatározása, dokumentálása, értékelése és/vagy tanúsítása céljából. A fóbb programelemek:

- az írástudás, a számtantudás és a digitális kompetenciák minimális szintjének elsajátítása; nemzeti sajátosságoktól függően az EKKR 3. vagy 4. szintű képesítés megszerzése felé haladva,

- kompetenciafejlesztési pályák tervezését a következő három lépésre alapozzák: készségfelmérés, személyre szabott, rugalmas és minőségi tanulási ajánlat biztosítása, valamint a megszerzett készségek érvényesítése és elismerése,

- koordináció és partnerség,

- megkeresési, iránymutatási és támogatási intézkedések,

- támogatja a tagállamok közötti tapasztalatcserét és elérhetővé teszi az európai felnőttképzés elektronikus platformján (EPALE) a legfontosabb forrásokat és információkat.

A panelbeszélgetés második felében a hozzászólók az alábbi kérdésköröket érintették:

A szakképző intézmények képviselői megerősítették, hogy a diákok nem tudnak írni, olvasni, számolni, és a kompetenciafejlesztés nem vagy csak nagyon alacsony szinten valósul meg a szakképzésben. Még mindig a frontális oktatás, a gondolkodás büntetése, az oktató utasításainak a követése dominál.

Másik hozzászóló a szakképző iskola a 9. osztályában reszocializációs feladatairól szól, mert csak ezután lehet bármi egyébbel foglalkozni. Felhívta a figyelmet a gyermekek körében jellemző szociális veszélyérzet hiányára: nem élik meg problémaként, hogy lemorzsolódik, hogy kiesik, hogy rossz jegyet kap... „Ráadásul a szülő sem látja!”.

Egy hozzászóló megjegyezte, hogy a szakképzés maradék elven múködik. Sokat el lehet érni a szakma elsajátításában, de nem tudjuk elérni, hogy olyan szakmunkássá váljon, aki képes alkalmazkodni a változásokhoz!

Megállapítást nyert: komoly probléma, hogy egyre több fiatal, nem fejezi be a 7-8.osztályt. Egyik megoldásként említik, hogy húzóerő lehet, hogy a jogosítvány megszerzéséhez 8 osztályos végzettség szükséges. Továbbá fontos lenne a mentor szerep megerősítése, és a pályaorientációs tanárok alkalmazása a szakképzésben. Amíg ez nincs, nem lesznek eredményesek a fejlesztő programok! 


\section{Életpálya és szakképzés}

Raportőri beszámoló a 4. panelbeszélgetés munkájáról (összeállította: Juhász Ágnes)

A rendszerváltozás utáni első szakképzési törvény 25. évfordulójára rendezett konferencia egyik szekcióját a pályaorientációnak szenteltük. A pályaválasztás és szakmai képzés határait a technológiai fejlődés számos ponton alakította és alakítja át ma is. A születéskor várható átlagélettartam folyamatosan növekszik Európában, miközben az alkalmazott technológia gyorsan változik. A pályaválasztás, pályaorientáció személyes döntés, amely az egyéni pályaelégedettséggel is összefügg. A modern munkaerőpiacokon leginkább a megfelelő egyéni én-hatékonyság és karrierrugalmasság teszi lehetővé a hosszú és gazdaságilag aktív pályavitelt.

A szekcióban három rövid előadásra került sor. Borbély-Pecze Tibor Bors, az MPT Pályaorientációs Szakosztályának elnöke a modern pályafutásokról beszélt. Előadásában kiemelte, hogy az ipari társadalmak felbomlóban vannak, és ez nem hagyhatja érintetlenül a pályák világát sem, amelyre a pályatanácsadásnak reagálnia kell. A klasszikus szakmunkás-életutakat és életpályaterveket egyre inkább felváltja egy rugalmasságot és többszöri pályadöntés-hozatalt megkívánó új világ, amely még csak most formálódik. Így a szakképzés és egyén, szakképzés és háztartás, vállalat, állam és társadalom viszonyrendszer is átalakulóban vannak. Nagy kérdés, hogy mikor jöhet létre Magyarországon egy olyan szakképzési rendszer, amely erre a paradigmára épül. Végül kiemelte az angol Barbara Bassot "híd-modelljét”, amelynek központi eleme Vigotszkij optimális fejlődési tér elmélete, amely a pályadöntés egyéni hangsúlyosságát és folyamatelvét hangsúlyozza. Ugyanakkor a modell mind a társadalom és gazdaság, mind az egyén fejlődési igényeit magába foglalja.

Fehérvári Anikó szakképzési pályakövetési kutatásokról számolt be, amelyek kapcsán néhány fontos általánosítható tényt mutatott be. Úgy, mint azt, hogy az érettségivel rendelkező szakmunkások elhelyezkedési esélyei és életpálya-jövedelmük magasabb, mint az értettségéivel nem rendelkezőké, illetve, hogy a 2000-es évek eleje óta folyamatosan nő az első helyen gimnáziumba jelentkezők aránya (28-ról $41 \%$-ra) a szakközépiskolába (ma szakgimnáziumba) jelentkezők rovására. A végzettség megszerzése nem jelenti a tanulmányok befejezését. A munkapiaci belépés a középiskolai korszak (18 évesek) után kitolódik, és még 2-3 évnyi további tanulással folytatódik. Egyes vizsgálatok szerint a végzett középiskolások estében átlagosan négy év telt el az elhelyezkedéséig. Az oktatás, szakképzés és a munkapiac kapcsolódására az egyik út az angolszász, ahol relatíve hosszú az általános képzési szakasz, a másik a német modell, ahol a szakképzés a közoktatás részeként korábban kezdődik. Ez utóbbi esetében a rövid távú elhelyezkedés gyors, de a karrierrugalmasság az egyének 40-50 éves korára gyengül. Heising és Solga (2015) 30-44 évesek PIAAC adataira építve azt az összefüggését találta, hogy amely országokban már alsó középfokban megjelenik a szakképzés, ott a felnőttek mért képességei alacsonyabbak. A későbbre helyezett pályaválasztásnak általában esélyegyenlőség növelő, korán végezve esélyegyenlőtlenséget növelő hatása van.

Mártonfi György a rendszerváltozás óta eltelt évtizedeket elemezte a szakképzés szerkezetváltozásainak és a pályaorientációnak a kapcsolódási szempontjából. Úgy értékelte, hogy az 1993-as szakképzési törvény előtti szakképzési rendszer és a 2011 után kialakult számos tekintetben hasonlítanak egymásra, miközben a 90-es években kialakított érettségire épülő szakképzési modell és a hosszú (10. osztály végéig tartó) orientáció újra kimentek a divatból. 
A bevezető előadásokat követő panelbeszélgetés résztvevői a következők voltak:

Danyi Vilmos NSZFH GINOP-6.2.4-VEKOP-16-2017-00001 „21. századi szakképzés és felnőttképzés” projekt pályaorienátciós komponensének vezetője.

Ütőné dr. Visi Judit, az OH EFOP 3.2.13 Az alap- és középfokú iskolák pályaorientációs tevékenységét, kiemelten az MTMI készségeket és kompetenciákat támogató pályaorientációs szakmai módszertan átfogó megalapozása és fejlesztése projekt szakmai vezetője.

Fürész István, a Székesfehérvári Önkormányzat A pályaorientáció eszközei a társasjátéktól a számítógéppel támogatott egyéni tanácsadásig programjának szakmai vezetője

A beszélgetést vezette: Juhász Ágnes

A felvezetésben elhangzott, hogy jelenleg soha nem látott lehetőségek vannak a pályaorientáció finanszírozására. Számos pályaorientáció témájú nagy projekt fut és számos projektnek van pályaorientációs része. Az MPT Pályaorientációs Szakosztálya fontosnak tartja, hogy ismerje ezeket a projekteket, és ha lehetséges, együttmúködjön velük. Annál is inkább, mert kis projekteknél a szakemberek bevonása problémát jelent, ugyanakkor sok a párhuzamosság. Felvetette, hogy a projektek között nincs együttmúködés. Kíváncsiak vagyunk arra, hogy a projektek vezetői hogy látják ezt a kérdést, van-e szándék az együttműködésre.

Kérdés: Kérjük, mutassák be a projektjüket! Beszéljenek arról, mennyiben felelnek meg a projekt célkitüzései az első előadásban elhangzott modern szemléletnek! Van-e a projektek között valamilyen együttmúködés? Ha nincs, szükségesnek látják-e és tervezik-e ezt a jövőben?

Visiné Ütő Judit: $\mathrm{Az} \mathrm{OH}$ projektjének célja az általános és középiskolákban a pályaorientációs tevékenység fejlesztése a tanárok képzésén keresztül. A fejlesztés másik eleme egy új mérőeszköz kifejlesztése, amelyben az MTMI szakmák bemutatásán van a hangsúly, de emellett komplex önismereti eszközként szolgál. (Kérdésre elmondta, hogy a mérőeszközök módszertanilag különböznek a Nemzeti Pályaorientációs Portálon elérhetőktől, azoknál komplexebbek és modernebbek lesznek.) A projekt harmadik lába a pályaorientációs fejlesztések összekötése, fórumok szervezése, amelyre a munka világának képviselőit is meg kívánják hívni. Fontosnak tartják a projektek közti együttmüködést, amely azonban még nem valósult meg. $\mathrm{Az} \mathrm{OH}$ és az NSZFH együttmúködése érdekében az első lépéseket már megtették.

Danyi Vilmos: Az NSZFH projektjének célja a szakképzés népszerúsítése. Cél, hogy a lehetőségeket megismerjék a tanulók, és ennek alapján eldönthessék, hogy érdekli-e őket. A projekt pályaorientációs pillérérének elsődleges célja a szakképzés népszerűsítése. Elemei:

az általános iskolások érdeklődésének felkeltése a szakképzés iránt rendezvénysorozatokkal (pl. Szakmák Éjszakája, Szakma Sztár, Európai Szakképzési Hét, Mi a pálya? pályaválasztási fesztivál, Építsd a jövőt! szakképzési fesztivál, shadow work program, Szakképzés napja)

- $\quad$ szakképzésben tanulók pályaszocializációjának támogatása, pályaorientációs tanárok képzése

- $\quad$ PORI módszertani központ kialakítása

- felnőtt lakosság életpálya-építésének megvalósítása

- $\quad$ tehetséggondozás

- pályaorientációs portál kialakítása

Elmondta, hogy a képzésre és a fejlesztésekre azért is szükség van, mert a 44 SZC-ben jövőre lesz egyegy főállású pályaorientációs szakértő és minden tagintézményben egy-egy pályaorientációs tanár, ami cca. 300-400 főt jelent. A jövőben számítanak különféle szereplők, köztük a kamarák közremúködésére is. 
Fürész István: Székesfehérváron 2012-ben városi szinten született meg a kezdeményezés. Alapgondolata, hogy az általános iskolákban az elkötelezett tanárok akkor tudnának segíteni, ha lennének iskolai pályaorientációs eszközök. (Pályaorientációs tanárokkal a megyében nem találkozott.) Bár az önkormányzat már nem iskolafenntartó, a társadalmi elköteleződése az ügy mellé állította, Az sem mellékes, hogy befektetők az önkormányzatot keresik meg azzal, hogy nincs megfelelő munkaerő. Mivel nem volt múködő rendszer - érdekorientált a pályaorientáció értelmezése, mást akar a kamara, a munkaadók, az iskola és a család -, az önkormányzat saját cégére telepítve indított saját programot, kiegészítve a kanadai donációból maradt 100.000 CAD-t. Ebben az életkorban a játék tűnt a megfelelő választásnak, ezért első lépésben társasjátékot fejlesztettek, amely bevezetés alatt áll. 2018. szeptembertől kapják meg ezeket az iskolák. Emellett készült egy füzet a tanárok számára is. (Kérdésre elmondta, hogy ezt más megyékben is hozzáférhetővé tudják tenni.) A játék és egyéb lehetőségek mellett biztosítani kell személyes segítség igénybe vételével a számítógéppel támogatott egyéni tanácsadást is. Ezt az iskolák általában nem tekintik feladatnak, de fontos érv az elzárkózással szemben a szakképzési törvény 85. § 5.6. bekezdése, amely szerint egy alkalommal mindenkinek jár általános iskolában pályaválasztási tanácsadás. Erről az iskolákban általában nem tudnak.

Kérdés: Mennyire látják reálisnak azt, hogy 14 éves gyerekeknek kell pályaválasztási döntést hozniuk, illetve nem látják el problémának, hogy a projekt célja egy adott irányban való befolyásolás.

Danyi Vilmos természetesnek tartotta, hogy ha az NSZFH a projektgazda, akkor a szakképzést kell népszerüsíteni - természetesen kényszer nélkül.

Visiné Ütő Judit jogosnak tartotta a kérdést, ők is felvetették ezt maguknak a fejlesztés kezdetekor, de véleménye szerint a projekt megoldásai megfelelőek. Hangsúlyozta, hogy az általános iskolások körében inkább önismeret-fejlesztés. megerősítés a cél, nem a konkrét pályaválasztás elősegítése. Inkább a középiskolásokat orientálják bizonyos pályák felé.

Fürész István hangsúlyozta, hogy az általános iskolásoknál még az érdeklődést sem lehet teljes mértékben felmérni, mivel annak három eleme közül csak a tevékenységre és a tanulmányi területre vonatkozó releváns ebben a korban - és még ez utóbbi is erősen tanárfüggő. A társadalmi szerepre vonatkozó érdeklődés középiskolás kor alatt nem vizsgálható. Fontos arra is figyelni, hogy az önértékelő eszközök személyes tanácsadás nélkül kontrollhiányosak lehetnek.

\section{Kérdés a közönséghez:}

- Vannak-e jelen olyanok, akik más pályaorientációs projektekben vesznek részt?

- Megfelelőnek tartják-e a jelenleg futó projekteket?

Pest Megyei Iparkamara: Ők is múködtetnek saját tanácsadó hálózatot. Fókuszban vannak az üzemlátogatások, ahol a gyerekek ki is próbálhatnak egyes feladatokat. A kipróbálást sokszor rendkívüli technika óraként hirdetik meg az SZC tanmúhelyeiben. (A hozzászólással kapcsolatban érdekes volt a közönség reakciója: A kamara képviselője azt gondolta, hogy ilyen tevékenységet csak ők végeznek a megyében, de többen jelezték, hogy ez nem így van.)

Kisgyermeknevelésben dolgozó hozzászóló: A „profik” által végzett pályaorientációnál, bemutatóknál hatékonyabb, ha a szülőket, tanulókat is bevonjuk. Ráadásul 7.-8. osztályban már késő az „érzékenyítés”, a kötelező üzemlátogatások nem motiválnak. A tanulókkal kellene ezt megtervezni, és csak oda menjenek, ahova kedvük van. Abban az intézményben, ahol dolgozott, az óvodások szülei 
vállalták, hogy bemutatják saját szakmájukat. A most már felnőtt óvodásainál látja, hogy ez hatékony volt, rugalmasabbak a fiatalok.

Tanext Szakképző Iskola tanára: A szakképző iskolákban is szükség van pályaorientációra. Példa: a 18 éves szakgimnáziumi érettségi előtt álló kereskedelmis fiatal már most tudja, hogy nem fog ebben a szakmában dolgozni. Neki ki segíti orientálódni? A szakközépiskolákban még nagyobb szükség van erre, mert a hátrányos helyzetú gyerekek nem tudják, mire jelentkeznek. Hiányszakmát választanak, hogy legyen ösztöndíjuk. De például szakácstanuló elmenekült a konyhai gyakorlatról, mert nem bírt több kiló hagymát megpucolni, Ebben az iskolában (alapítványi) 4 évre összerakott belső program van önismeret-fejlesztésre, pályaorientációra. A szakközépiskolásokat fél év önismeret-fejlesztés után hat hetes szakaszokban különféle szakmákra viszik gyakorlatra, és lehetőségük van váltani. Megoldják, hogy ne kelljen emiatt évet veszíteniük. Ezt azonban rendszerbe kellene illeszteni, mert így csak azokat a szakmákat tudják megmutatni, amelyeket ők képeznek. (Szakképző Centrumokban ez megoldható lenen.)

Az együttmüködésről: A TÁMOP 2.2.2 második szakaszában rendezett képzések ma is összekapcsolják a gyakorlati szakembereket. A hozzászóló megyéjében együttmúködik a kamara, a szakszolgálat, a szakképzési centrum és a kormányhivatal.

\section{Összefoglalóan:}

Idő hiányában a panel nem tudott kellő mélységben foglalkozni a hiányosságokkal, javaslatokkal. Annyi mindenesetre kiderült, hogy az informáltság a projektekről, egymás munkájáról, illetve a projektek, programok együttmúködése nagyon hiányos (bár helyi szinten vannak jó példák).

A pályaorientációban a hangsúly az általános iskolások továbbtanulási döntésének segítésén, sokszor befolyásolásán van, kiegészítve a gimnazisták továbbtanulási döntésének MTMI irányba való befolyásolásával. Holott - mint az néhány hozzászólásból kiderült - már óvodától és a szakképzésben is nagy szükség lenne pályaorientációra, ennek jó példáit is hallhattuk. 